\title{
Analysis of Factors Affecting the Effectiveness of Training: An Empirical Study of Basic Training Program (Latsar) for the Probationary Civil Servant (CPNS) at the Ministry of Research, Technology and Higher Education held at BPSDM Central Java Province
}

\author{
Erni Irawati ${ }^{1}$, Endang Larasati ${ }^{2}$, Hardi Warsono ${ }^{3}$, Sundarso $^{4}$ \\ \{larasati57@ymail.com²\} \\ Universitas Diponegoro, Indonesia ${ }^{1,2,3,4}$
}

\begin{abstract}
The overarching aim of this descriptive-correlational study was to evaluate the effectiveness of a Basic Training for Prospective Civil Servants at the Ministry of Research, Technology, and Higher Education at the Regional Human Resources Development Agency in Central Java Province. To evaluate the effectiveness of the respective program, the researcher examined the relationship between classroom environment, participant motivation, and learning facilities. This study employed purposive sampling technique to draw a sample of 95 respondents from a population of 521 training participants through self-administered questionnaire to examine the influence of three variables including classroom environment, participant motivation, and learning facilities on the effectiveness of training on the effectiveness of the training. The findings of the study generally revealed that the effectiveness of training is affected by the three variables; namely classroom environment, participant motivation, and learning facilities. Therefore, the Regional Human Resources Development Agency in Central Java Province should; 1) restrict the class size with 30 trainees in one class, 2) prepare the learning facilities well before the classes; 3) improve trainers' competences, motivation and job-satisfaction to improve the effectiveness of trainings.
\end{abstract}

Keywords: Classroom Environment, Participant Motivation, Learning Facilities, Effectiveness of Training.

\section{Introduction}

Education and Training is one of the instruments for developing the capacity of the State Civil Apparatus, which is considered being effective to improve and develop the State Civil Apparatus' knowledge, skills and attitudes simultaneously. The implementation of the development of State Civil Apparatus' competencies can be conducted through education and training in a variety of methods or techniques, such as classroom learning, non-class learning and a combination of both methods. There are advantages and disadvantages in every technique, and the training method options are not one-size-fits-all. 
Classroom-learning is considered as a conventional method in teaching and learning because the method involves direct interaction between the trainer and training participants (trainees). This classroom learning method considered the best method to facilitate the three types the trainees' way of learning, including visual, auditory and kinesthetic types of learning, because it involves gestures, expressions, movements and other activities that represent the message of training.

However, classroom-learning method is not a method without weaknesses. The process of direct interactions between trainees and trainers require factors that can influence conduces learning atmosphere, such as classroom condition, learning facilities and infrastructure, learning media, and learning motivation. The absence of one of those factors above often causes an ineffective classroom learning process.

The object in this research is Basic Training Program (Latsar) for the Probationary Civil Servant (CPNS) at the Ministry of Research, Technology and Higher Education held at BPSDM Central Java Province. During implementation of the classroom learning process there are several indicators encountered that characterize the overall quality of teaching and learning. Some of those indicators include good classroom condition, trainees' learning motivation, available learning facilities and infrastructure, which are not reflecting the process of effective learning. These three factors are conditio sine quanon (prerequisites) for the effectiveness of classroom learning in training.

This article aimed at providing an overview of the contributions of those three factors to the effectiveness of classroom learning method applied in Basic Training Program (Latsar) for the Probationary Civil Servant (CPNS) at the Ministry of Research, Technology and Higher Education held at BPSDM Central Java Province.

The limitations of this study is only three research components are involved namely classroom condition, participant motivation, and learning facilities. Other factors that might also influence the effectiveness of the training such as learning materials and trainers' competencies were not analyzed.

\subsection{Formulation of the Problem}

Further discussion in this section will include the following issues as follows:

a) Is there any correlation between classroom condition and the effectiveness of Latsar Training for the CPNS at the Ministry of Research, Technology and Higher Education at BPSDMD Central Java Province?

b) Is there any correlation between the trainees' motivation and the effectiveness of Latsar Training for the CPNS at the Ministry of Research, Technology and Higher Education at BPSDMD Central Java Province?

c) Is there any correlation between the learning facilities and the effectiveness of Latsar Training for the CPNS at the Ministry of Research, Technology and Higher Education at BPSDMD Central Java Province?

\subsection{Research Purposes}

Based on the problems formulated above, the objectives of this study are:

a) To find out the correlation between classroom condition and the effectiveness of Latsar Training for the CPNS at the Ministry of Research, Technology and Higher Education at BPSDMD Central Java Province. 
b) To find out the correlation between the trainees' motivation and the effectiveness of Latsar Training for the CPNS at the Ministry of Research, Technology and Higher Education at BPSDMD Central Java Province.

c) To find out the correlation between the learning facilities and the effectiveness of Latsar Training for the CPNS at the Ministry of Research, Technology and Higher Education at BPSDMD Central Java Province.

\subsection{Hypotheses}

The hypothesis to be tested in this study is there is not any correlation between classroom condition, participant motivation, learning facilities and the learning effectiveness of Latsar Training for the CPNS at the Ministry of Research, Technology and Higher Education at BPSDMD Central Java Province (Ha). For the purpose of hypothesis testing, that hypothesis is changed to null hypothesis (Ho), so that it becomes:

a) There is any correlation between classroom condition and the effectiveness of the Latsar Training CPNS Kemenristek Dikti at BPSDMD Central Java Province.

b) There is any correlation between trainees' motivation and the effectiveness of learning of the Latsar Training of CPNS Kemenristek Dikti at BPSDMD of Central Java Province.

c) There is any correlation between learning facilities with the effectiveness of learning Latsar Training CPNS Kemenristek Dikti at BPSDMD Central Java Province.

\section{Literature Review}

\subsection{Class Condition}

Referring to the Big Indonesian Dictionary (KBBI-online) the word "condition" means circumstance. While the class definition according to Hamalik [1], class is a group of people who participate in learning activities that involves teaching from a teacher. This understanding is clearly viewed in terms of students because in that sense there is a phrase group of people. So, the condition of the class is the condition of a group of people who conduct teaching and learning activities together that involves the teaching from the resource persons.

Class condition relates to class management, which refers to Nurhadi [2] class management is an effort to manage students in the class conducted to create and maintain classroom conditions that support the teaching program by creating and maintaining student motivation to always be involved and participate in the process education in school.

Sidi (1996) in Cope (2002), emphasized that in the implementation of learning activities, each learner must be able to create a pleasant learning atmosphere, an atmosphere of lively learning interactions, develop appropriate media, utilize appropriate learning resources accordingly, motivating students to participate in the learning process, and a conducive learning condition in the classroom. In order for learning to be truly conducive, the learner has a very important role in creating the conditions of learning.

\subsection{Motivation}

According to Handoko [3], motivation is interpreted as a condition in a person that encourages the desire of individuals to carry out certain activities in order to achieve goals. 
Motivation is a factor that drives a person to do a certain activity, because motivation is often interpreted as a factor driving a person's behavior. Every activity carried out by someone must have something that drives the activity. Therefore, the driving factor of a person to carry out a certain activity in general is the person's needs and desires [4].

The Maslow model [3] is often called the needs hierarchy model. Because it involves human needs, then this theory is used to show someone's needs that must be met so that the individual is motivated to work. According to Maslow, in general there is a hierarchy of human needs, which can be seen the following level of needs:

a) Physical needs

b) Security needs

c) Social needs

d) Need for self-esteem

e) Actualization needs

Theory of Need proposed by McClelland in Sutrisno [5] is also called achievement motivation theory. According to this theory there are three basic components that can be used to motivate people to work, namely:

a) Need for achievement Is the need to achieve success, which is measured by the standard of perfection in a person. This need, is closely related to work, and directs behavior toward efforts to achieve certain achievements.

b) Need for affiliation Is a need for warmth and support in relationships with others. This need directs behavior to make close relationships with others.

c) Need for power

The need to control and influence others. This need causes the person concerned to not care about the feelings of others. Further explained in everyday life.

\subsection{Learning Facilities}

Referring to the Big Indonesian Dictionary (KBBI), learning facilities are all things that can be used as a tool in achieving goals or objectives. While learning tools are learning equipment needed in the learning process so that the achievement of learning goals can run with fluent, orderly, effective and efficient.

According to Arsyad [6], the use of learning facilities provides several benefits, namely:

a) Utilization of learning facilities can clarify messages and information so that they can expedite and improve the process and learning outcomes

b) Increase and excite children's attention so that it can lead to motivation to learn, more direct interaction between students and their condition and allows students to learn on their own according to their ability to interest

c) Provide a common experience to students about the events in their condition, as well as allowing direct interaction with the teacher, the community and the condition, for example through field trips and others.

\subsection{Effectiveness of Learning}

According to Miarso [7], learning effectiveness is what produces learning that is beneficial and aims for students, through appropriate learning procedures. The effectiveness of learning is often measured by the achievement of learning objectives, or accuracy in managing 
a situation. Some things contained in this definition, namely the effectiveness of learning is an educational activity that has characteristics, namely (1) systemic, which is carried out through the stages of planning, development, implementation, assessment, and improvement. (2) sensitive to the need for learning assignments and the needs of learners. (3) clarity on the purpose and cause of that effort can be collected to achieve it. (4) starting from the ability or strength of students, educators, the community, and the government.

According to Riyanto (2003), learning effectiveness is defined as being effective or effective, or achieving the goals or achievement of learning objectives. According to Firman (1997) the effectiveness of learning programs is characterized by the following characteristics:

a) Successfully deliver students to achieve instructional goals that have been set.

b) Provide an attractive learning experience, involving students actively so as to support the achievement of instructional goals.

c) Having facilities that support the teaching and learning process

\section{Research Methods}

\subsection{Types of Research}

This research is a descriptive-correlational study, which wants to draw a conclusion between an independent variable, namely class conditions, participant motivation, and supervisory learning facilities and learning effectiveness in the basic training process of the CPNS Kemenristek Dikti.

\subsection{Population and Sample}

The population of this study was all participants of the basic training of probationary civil servants at the Kemenristek Dikti, totaling 521 training participants divided into 14 batches. From this population, a sample of 95 respondents was taken, in which non-random purposive sampling was taken. Purposive sample is a sampling technique with certain considerations [8]. The basis used to determine the number of samples refers to Gay opinion. According to Gay in Umar [9] that the minimum sample size that can be accepted is based on the research design used, which is as follows:

a) Descriptive method is at least $10 \%$ of the population. For a relatively small population of at least $20 \%$ of the population

b) Descriptive-correlational method, a minimum of 30 subjects

c) ex post facto method, a minimum of 15 subjects per group

d) Experimental method, a minimum of 15 subjects per group

So, referring to the provisions the sample of this study is amounted to 95 subjects already fulfilling the requirements of correlation testing.

\subsection{Data Type}

There are two types of data in this study, namely primary data and secondary data. 
a) Primary Data

Primary data is data obtained directly from the original source and has not been processed data. Included in the primary data of this study were questionnaire results from respondents.

b) Secondary Data

Secondary data is data obtained indirectly from the original source or data that has been processed. Secondary data included in this study include population data, samples, and literature review.

\subsection{Method of Collecting Data}

Data collection was carried out by questionnaire, interview, and literature study methods.

a) Questionnaire is a written question given to the respondent to get an answer / response from a statement of attitude.

b) Interview, which is a way of collecting data by asking questions then listening to answers directly from the main source of data, or followed up with written answers from the data source.

\subsection{Statistical Analysis Approach}

This study uses a non-parametric statistical approach in the analysis of statistical tests, because the characteristics of the samples taken are homogeneous, especially in terms of work background and educational strata. In addition, in the initial research testing it was found that the research data were not normally distributed. So this study did not conduct a classical assumption test in statistical analysis.

\subsection{Analysis Tool}

Testing of research instruments is done by testing the validity and reliability.

a) The validity of an instrument indicates the extent to which the measuring device is able to measure what it wants to measure.

b) The reliability of an instrument shows the level of how much a gauge measures stably and consistently.

\subsection{Hypothesis Testing Tools}

Since the approach used is non-parametric statistics, to determine the strength of the correlation between research variables, this study uses the Spearman Rank and Kendal-Tau correlation hypothesis test.

\subsection{Data Analysis}

\subsubsection{Test Research Instruments}

a) Testing validity

In testing the validity of measuring instruments, this study uses the Product Moment Correlation formula, which is processed through SPSS software. The validity decision is determined by comparing the $r$ count with $r$ table. The testing steps are as follows: 
- Determine the table.

The table for this study sample was 95 and the significance level of $5 \%$ was 0.202 .

- Determine the decision criteria

Criteria for recognition of an instrument declared valid or not are: 1) Items that have a correlation ( $\mathrm{r}$ count) $\geq 0.202$ are declared valid. 2) Items that have a correlation ( $\mathrm{r}$ count $<0.202$ are declared invalid.

- Perform the calculation of the coefficient $r$ ( $r$ count) and comparison with $r$ table.

- Taking the conclusion of the validity test

The results of the comparison between $r$ count and $r$ table are presented in Table 1 shows that all the coefficients of $r$ count on each variable statement items both class conditions, participant motivation, means of learning, and learning effectiveness are greater than $r$ table so that all instruments are declared valid, then it can be used as research instruments.

b) Reliability Test

Reliability testing uses Cronbach's Alpha benchmarks. The measuring instrument is declared reliable if Cronbach's alpha is more than 0.6. Here are the results of alpha Cronbach calculations with SPSS software.

The table above compares the alpha coefficient (alpha Cronbach) with the required threshold of 0.6 , the result is that all alpha coefficients of the classroom conditions measuring instrument, participant motivation, learning tools, and learning effectiveness are greater than 0.6 so that the measuring instrument is declared reliable, Furthermore, it can be used as a research instrument.

\subsubsection{Hypothesis Testing}

The steps of testing the hypothesis with Spearman Rank and Tau Kendal correlation analysis are as follows:

a) Determine Ho and $\mathrm{Ha}$

- The correlation between classroom conditions and learning effectiveness, the alternative hypothesis testing is:

Ho: $\beta 1=0$ means that there is no significant relationship between classroom conditions and learning effectiveness.

Ha: $\beta 1 \neq 0$ means that there is a significant relationship between classroom conditions and learning effectiveness.

- The correlation between participant's motivation and learning effectiveness, the alternative hypothesis testing is:

Ho: $\beta 2=0$ means that there is no significant relationship between participant motivation and learning effectiveness.

Ha: $\beta 2 \neq 0$ means that there is a significant relationship between participant's motivation and learning effectiveness.

- The correlation between learning tools and learning effectiveness, the alternative hypothesis testing is:

Ho: $\beta 2=0$ means that there is no significant relationship between learning tools and learning effectiveness.

Ha: $\beta 2 \neq 0$ means that there is a significant relationship between learning tools and learning effectiveness.

b) Determine the level of significance

The level of significance is set at 0.05 
c) Determine testing criteria

- Pvalue $\geq 0.05$, then $\mathrm{H} 0$ is accepted

- Pvalue $<0.05$ then $\mathrm{H} 0$ is rejected and then receives Ha.

d) Calculate the pvalue

The pvalue results with SPSS are presented in Table 3 below:

\subsection{Make a Decision}

Based on Table 3, the acceptance and rejection hypothesis analysis can be carried out as follows:

a) The relationship between classroom conditions and learning effectiveness:

The SPSS calculation results show that:

- Kendal Tau's p value of $0.00<0.05, \mathrm{H} 0$ is rejected then accepts Ha, meaning that there is a significant relationship between classroom conditions and the learning effectiveness of CPNS Latsar Education and Training participants of Kemenristek Dikti in BPSDMD Central Java Province.

- These results are strengthened by the Spearman Rho pvalue of $0.00<0.05$.

b) The relationship between participant motivation and learning effectiveness:

The SPSS calculation results show that:

- Kendal Tau's p value of $0.00<0.05, \mathrm{H} 0$ is rejected then accepts Ha, meaning that there is a significant relationship between participant's motivation and the learning effectiveness of CPNS Latsar Education and Training participants of Kemenristek Dikti in BPSDMD Central Java Province.

- These results are strengthened by the Spearman Rho pvalue of $0.00<0.05$.

c) The relationship between learning tools and learning effectiveness:

The SPSS calculation results show that:

- Kendal Tau's p value of $0.00<0.05, \mathrm{H} 0$ is rejected then accepts Ha, meaning that there is a significant relationship between learning facilities and the effectiveness of learning of CPNS Latsar Education and Training participants of Kemenristek Dikti in BPSDMD Central Java Province.

- These results are strengthened by the Spearman Rho pvalue of $0.00<0.05$. Qualitative analysis.

Sarwono (2006) gives a classification of the magnitude of the correlation coefficient, namely:

a) Correlation coefficient of zero means that there is no correlation between variables.

b) Correlation coefficient of 0.01 to 0.25 means the correlation between variables is very weak.

c) Correlation coefficient of 0.26 to 0.50 means the correlation between variables is strong enough.

d) Correlation coefficient of 0.51 to 0.75 means the correlation between variables is strong.

e) Correlation coefficient of 0.76 to 0.99 means the correlation between variables is very strong.

f) Correlation coefficient of 1 means the correlation between variables is perfect.

Based on this classification, the relationships between the variables of this study are stated as follows:

a) Hypothesis test results indicate that classroom conditions have a significant relationship with learning effectiveness, while the magnitude of the Kendal Tau correlation coefficient of 0.392 means the classroom conditions and learning effectiveness have a strong enough 
relationship. The correlation coefficient is of a positive magnitude which means that classroom conditions with learning effectiveness have a direct relationship, the better the classroom conditions, the more effective the learning.

b) Hypothesis test results indicate that participant motivation has a significant relationship with learning effectiveness, and is characterized by a Kendal Tau correlation coefficient of 0.294, meaning that participant motivation and learning effectiveness have a strong enough relationship. The correlation coefficient is positive, it means that the motivation of participants with learning effectiveness has a direct relationship, the greater the motivation of the participants, the more effective the learning.

c) Hypothesis test results indicate that learning facilities have a significant correlation with learning effectiveness, while the magnitude of the correlation coefficient Kendal Tau 0.308 , meaning that learning tools and learning effectiveness have a strong enough relationship. The correlation coefficient is of a positive magnitude meaning that learning means with learning effectiveness have a direct relationship, the better the learning means, the more effective the learning.

\section{Conclusions}

The results of this study can be concluded that:

a) Class conditions have a moderate strong correlation with the effectiveness of learning Latsar Training CPNS Kemenristek Dikti in BPSDMD Central Java Province, and the relationship between the two variables is unidirectional.

b) Motivation of participants has a strong correlation with the effectiveness of learning Latsar Training CPNS Kemenristek Dikti in BPSDMD Central Java Province, and the relationship between the two variables is unidirectional.

c) Means of learning have a strong correlation with the effectiveness of learning CPNS Latsar Training Kemenristek Dikti in BPSDMD Central Java Province, and the relationship between the two variables is unidirectional.

\subsection{Recommendations}

a) The ideal number of training participants is 30 people in one class because the number of participants less than or more than 30 people will affect the effectiveness of learning.

b) Learning facilities should be checked for the readiness of their functions every day before the learning process so that problems that arise in the learning process from the aspect of facilities can be minimized.

c) The role of Widyaiswara as a facilitator in controlling the class and motivating participants is needed so that the learning process becomes more effective.

\section{References}

[1] O. Hamalik, "Pengembangan Sumber Daya Manusia Manajemen Pelatihan Ketenagakerjaan Pendekatan Terpadu," Proses Belajar Mengajar, 2011.

[2] F. Nurhadi, "Strategi Pengembangan Pariwisata Oleh Pemerintah Daerah Terhadap Pendapatan Asli Daerah (PAD) (Studi Pada Dinas Pemuda, Olahraga, Kebudayaan Dan Pariwisata Kabupaten Mojokerto),"J. Adm. Publik Mhs. Univ. Brawijaya, vol. 2, no. 2, pp. 325-331, 2014. 
[3] T. H. Handoko, "Manajemen edisi 2," Yogyakarta BPFE, 2003.

[4] I. Gitosudarmo, "Manajemen strategis," Yogyakarta BPFE Yogyakarta, 2001.

[5] E. Sutrisno, "Manajemen Sumber Daya Manusia Edisi pertama," Jakarta Kencana Prenada Media Gr., 2009.

[6] L. Arsyad, "ASSESSING FACTORS AFFECTING THE REPAYMENT RATE OF MICROFINANCE INSTITUTIONS.," Gadjah Mada Int. J. Bus., vol. 8, no. 2, 2006.

[7] Y. Miarso, "Landasan Berpikir dan Pengembangan Teori dalam Penelitian Kualitatif," $J$. Pendidik. Penabur, no. 5, pp. 63-71, 2005.

[8] Sugiyono, Metode Penelitian Pendidikan Pendekatan Kuantitatif, Kualitatif, dan $R \& D$. Bandung: Alfabeta, 2009.

[9] S. Umar, "Why Standard of Teacher Education is falling. Retrieved 28th October." 2005. 